\title{
Slaughter and Meat Qualities of Experimental Store Pigs \\ Alexey Kozlikin
}

Candidate of Agricultural Sciences, Associate Professor of Food Technology Department, Don State Agrarian University, Russia

\section{ORCID:}

Alexey Kozlikin: http://orcid.org/0000-0001-6555-941X

\section{Abstract}

This study was carried out on the fattening and meat qualities of store pigs. One of the main tasks of the study was to analyze the meat quality of the progeny obtained through the crossing of LW female pigs and half-breed LW $\times$ ST with male pigs of specialized meat breeds. Linear sizes were defined, which served as an indirect indicator of meat productivity. The amount of pig fat in a carcass was determined. The animals of the $1^{\text {st }}$ and $2^{\text {nd }}$ groups were distinguished $-30.8 \%$ and $32.1 \%$, respectively, which were higher than the animals of the triple crossing by 2.5\% $(P<0.95) ; 3.0 \%(P<0.95) ; 3.8 \%(P>0.99)$;

Corresponding Author: Alexey Kozlikin KozlikinAV@mail.ru

Published: 5 April 2021

Publishing services provided by Knowledge E

(c) Alexey Kozlikin. This article is distributed under the terms of the Creative Commons

Attribution License, which permits unrestricted use and redistribution provided that the original author and source are credited.

Selection and Peer-review under the responsibility of the DonAgro Conference Committee. 3.9\% ( $P>0.999) ; 4.3 \%$ ( $P>0.999)$; and 5.1\% ( $>>0.999$ ). According to our data, the highest indicator of the loin eye area was among the pigs obtained through the crossing of crossbred female pigs LW $\times$ ST with male pigs of Pietrain, Duroc, Landrace breeds. The triple crossing pigs had the highest slaughter yield $-72.4-73.3 \%$, compared to 69.4\% for LW, and 70.5\% for the two-breed rotation LW $\times$ ST. In terms of bone content, the differences were not significant and were statistically unreliable. The two-breed pigs LW $\times$ ST had the largest amount of kidney fat followed by LW and all of the triple crossed pigs. However, the difference was not statistically significant. The weight of the carcasses in the experimental groups ranged from $60.7 \mathrm{~kg}$ to $65.3 \mathrm{~kg}$, and the pigs of the $3^{\text {rd }}, 4^{\text {th }}$ and $5^{\text {th }}$ groups had the largest carcass weights, while the highest indicator was observed in the combination $(\mathrm{LW} \times \mathrm{ST}) \times \mathrm{D}$.

Keywords: pigs, meat quality, muscles, pig fat.

\section{Introduction}

Crossbreeding hybridization has recently gained considerable attention, which provides for the breeding of pigs with specialized lines, types and breeds and their crosses for more efficient use of heterosis based on industrial crossing. Therefore, an important factor towards the increase of heterosis during crossing, and especially hybridization, is the study of the effect of breeds and lines on their combination ability, which allows not only significantly increasing the productivity of pigs, but also improving the quantitative and qualitative indicators of meat. At the same time, there is a need to study the 
efficiency of purebred breeding and crossbreeding of various most common genotypes of pigs [1].

In industrial complexes, it is most effective to use crossbreeding, which allows improving the reproducing qualities of female pigs, meat and fattening qualities of young animals, where the female pigs of Large White and Landrace breeds are used as female parent, and the male pigs of synthetic line of Irish selection - as paternal breed [2]. The highest meatness and leanness of carcasses was in pigs obtained from the combination of Large White female pigs with Landrace male pigs of Finnish selection [3].

The criteria for assessing the quality of carcasses include the carcass length, percentage of meat in a carcass, fat depth, ham side weight mass, and the loin eye area. All these characteristics are determined after the control fattening during special carcass cutting [4]. The Large White pig breed has a strong constitution, well adapted to feed and climatic conditions of the Central Chernozem Zone. The animals of this breed are mainly used as the female parent for industrial crossing and hybridization in commercial farms [5].

The results of fattening qualities of experimental pigs indicate that the use of male pigs of specialized meat breeds in different versions of triple crossing improves speed, growth energy and feed conversion [6].

The physical properties of pig meat are influenced by several factors, namely, genotype, breed and animal body weight. With the increase of the body weight before slaughter up to $130 \mathrm{~kg}$ the slaughter weight, slaughter yield, carcass length, ham weight, loin eye area and fat depth of crossbred animals also increased [7].

To increase the production of meat pork and improve its quality, it is recommended to use Duroc, Landrace and Pietrain pigs in the pig breeding system in Rostov region [8]. The meat productivity of triple crossings is largely determined by the pre-slaughter body weight [9]. In order to improve the fattening and meat qualities of Large White pigs, it is advisable to use their industrial crossing with male pigs of Landrace specialized meat breed [10].

The quality of obtained products is an important link in the chain of profitable pig farming - a key indicator characterizing the value of the carcass of processed animals. The use of two-breed animals $(L W \times D)$ for the production of pork has a positive effect on fattening, slaughter and meat qualities [11].

The most multiparous were the combination of hybrid female pigs $(L W \times D)$ with Duroc male pigs. Hybrid piglets from the $1^{\text {st }}$ and $2^{\text {nd }}$ groups obtained from the combination of Large White $x$ Landrace breeds of Canadian and Danish selection with Duroc male pigs were characterized by the best growth rate during sucking and growing periods. 
According to fattening and slaughtering qualities of hybrid young pigs, the best results are obtained when combining female pigs ( $L W \times Y$ ) with Landrace male pigs of Canadian selection and also when combining female pigs $(\mathrm{LW} \times \mathrm{Y})$ with Landrace male pigs of Danish selection. To increase the production of pork and improve its quality in industrial conditions, it is recommended to use Landrace male pigs of Canadian and Danish selection at the final stage of triple crossing - Large White $x$ Yorkshire $x$ Landrace, as well as Duroc male pigs when crossing with hybrid female pigs (LW $\times$ L Danish) [12].

The quality of carcasses and pig meat is influenced by the genotype and the body weight of animals before slaughter. A key factor in improving the quality of pig meat is the use of industrial crossing of large white with meat breeds, such as Duroc and Landrace [13].

In order to increase the production of meat pork and reduce its cost, it is promising to create pedigree breeding units for Duroc, Landrace and Pietrain pigs, as well as commercial farms for producing crossbred female pigs LW $\times$ ST and their further use in the pig breeding system in Rostov region when crossing with male pigs of specialized meat breeds $[14,15]$.

\section{Methods and Equipment}

The experiments used purebred female pigs of Large White breed (LW) and crossbred pigs of LW $x$ Steppe Type (ST), crossbred piglets obtained using the male pigs of Duroc (D), Landrace (L), Pietrain (P) and Middle White breeds (MW-1). According to the experimental scheme, 5 groups of female pigs were formed: 1 group - purebred female pigs LW; 2 group - crossbred female pigs LW $\times$ ST; 3, 4, 5 groups - crossbred female pigs LW $\times$ ST with assigned male pigs of corresponding breeds: Pietrain (P), Duroc (D), Landrace (L).

The control and experimental groups were formed according to the principle of analogues, taking into account the age and development of animals (first litter gilt were used).

The studies were conducted according to the following scheme (Table 1).

Female pigs were mounted twice per mating with the same male pig - immediately after heat detection and again after 24 hours. The first three days after mating, the female pigs were kept in individual quarters and then in group cages.

The studies used balanced diets providing animals with energy, nutrients and biologically active substances. The feeding type was concentrated and the supplements included animal feed (whole milk, skimmed milk, meat-and-bone scraps, protein, vitamin 
TABLE 1: Experimental scheme

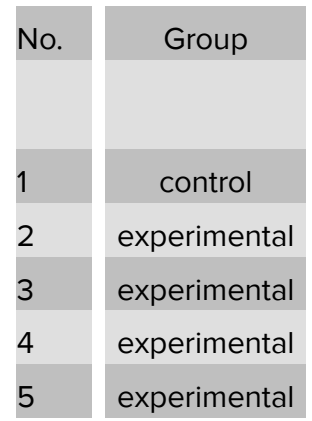

\begin{tabular}{|c|c|}
\hline \multicolumn{2}{|c|}{ Selection option } \\
\hline $\begin{array}{c}\text { female pigs } \\
\text { свиноматKи }\end{array}$ & male pigs \\
\hline LW & LW \\
\hline LW & ST \\
\hline LW $\times$ ST & P \\
\hline LW $\times$ ST & L \\
\hline LW $\times$ ST & D \\
\hline
\end{tabular}

\begin{tabular}{|c|c|}
\hline \multicolumn{2}{|c|}{ Headcount } \\
female pigs & male pigs \\
\hline 12 & 3 \\
\hline 12 & 3 \\
\hline 12 & 3 \\
\hline 12 & 3 \\
\hline 12 & 3 \\
\hline
\end{tabular}

and mineral supplements). The diets were compiled taking into account age, body weight, productivity and physiological condition.

To study fattening and meat qualities, the groups of piglets ( 36 heads each) of every crossing option were formed immediately after weaning.

Animal feeding and management was carried out according to the OST-103-86 Pigs. Control fattening method.

The $\mathrm{pH}$ (acidity unit), color intensity (color density unit), moisture-retaining capacity of meat (\%) were determined in samples taken from the rib eye 48 hours after slaughter.

\section{Results}

The analysis of control slaughter results (Table 2 ) indicates that in terms of pre-slaughter weight the differences between experimental animals were not significant.

In terms of the head weight, the triple crossing piglets were below their purebred LW herdmates by 0.1-0.2 kg, and two-breed LW $\times$ ST piglets by 0.2-0.3 $\mathrm{kg}(\mathrm{P}<0.95)$.

The carcass weight of experimental animals ranged from 60.7 to $65.3 \mathrm{~kg}$, and the largest carcass weight was typical for the piglets of the $3^{\text {rd }}, 4^{\text {th }}$ and $5^{\text {th }}$ groups, which amounted to $64.2-65.3 \mathrm{~kg}$, while the highest indicator was typical for (LW $\times$ ST) $\times$ D $65.3 \mathrm{~kg}$.

Triple crossing piglets had the highest slaughter yield - 72.4-73.3\% compared to LW - 69.4\%, the slaughter yield of two-breed LW x ST piglets was $70.5 \%$.

The modern stage of pig farming development is characterized by the demand of the population for leaner pork. For this purpose, along with purebred breeding, various methods of crossbreeding and hybridization are increasingly being used. The study of domestic and foreign researchers suggests the expediency of producing meat pork and improving the meat qualities of crossbred young pigs using Large White breed. Table 3 shows the analysis of the meat qualities of obtained progeny in the slaughter 
of young pigs. One of the key indicators that characterize the carcass meat is the linear size, which is an indirect indicator of meat productivity.

Three-breed piglets had the thinnest layer of fat $(\mathrm{LW} \times \mathrm{ST}) \times \mathrm{D}-27.1 \mathrm{~mm}$, and the difference in this indicator compared to the animals of the control group was $13.7 \%$ $(P>0.999)$.

The fat depth of piglets (LW $\times \mathrm{ST}) \times \mathrm{P}$ and $(\mathrm{LW} \times \mathrm{ST}) \times \mathrm{L}$ was 27.4 and $27.3 \mathrm{~mm}$, respectively, and was less than their herdmates of the control group by $12.8(P>0.999)$ and $13.1 \%(P>0.999)$. The animals from LW $\times$ ST combination had the largest fat depth - 31.8 versus $31.4 \mathrm{~mm}$ in LW herdmates.

TABLE 2: Results of control slaughter at $100 \mathrm{~kg}$ body weight

\begin{tabular}{|c|c|c|c|c|c|c|c|c|c|}
\hline Group & Combination & $\mathrm{n}$ & $\begin{array}{c}\text { Pre- } \\
\text { slaughter } \\
\text { weight, kg }\end{array}$ & $\begin{array}{c}\text { Carcass } \\
\text { weight, kg }\end{array}$ & $\begin{array}{c}\text { Head } \\
\text { weight, } \\
\text { kg }\end{array}$ & $\begin{array}{l}\text { Leg } \\
\text { weight, } \\
\text { kg }\end{array}$ & $\begin{array}{c}\text { Kidney } \\
\text { fat } \\
\text { weight, } \\
\text { kg }\end{array}$ & $\begin{array}{l}\text { Slaughter } \\
\text { weight, kg }\end{array}$ & $\begin{array}{c}\text { Slaughter } \\
\text { yield, \% }\end{array}$ \\
\hline I & LW & 5 & $100.0 \pm 0.6$ & $60.7 \pm 0.1$ & $5.0 \pm 0.1$ & $1.7 \pm 0.1$ & $2.0 \pm 0.1$ & $69.4 \pm 0.4$ & 69.4 \\
\hline ॥ & $\mathrm{LW} \times \mathrm{ST}$ & 5 & $99.9 \pm 0.7$ & $61.5 \pm 0.2$ & $5.2 \pm 0.1$ & $1.8 \pm 0.1$ & $2.0 \pm 0.1$ & $70.5 \pm 0.5$ & 70.5 \\
\hline III & $(\mathrm{LW} \times \mathrm{ST}) \times \mathrm{P}$ & 5 & $100.1 \pm 0.5$ & $64.6 \pm 0.2$ & $4.8 \pm 0.1$ & $1.6 \pm 0.1$ & $1.8 \pm 0.1$ & $72.7 \pm 0.4$ & 72.6 \\
\hline IV & $(\mathrm{LW} \times \mathrm{ST}) \times \mathrm{L}$ & 5 & $100.3 \pm 0.6$ & $64.2 \pm 0.3$ & $4.9 \pm 0.1$ & $1.7 \pm 0.1$ & $1.8 \pm 0.1$ & $72.6 \pm 0.6$ & 72.4 \\
\hline V & $(\mathrm{LW} \times \mathrm{ST}) \times \mathrm{D}$ & 5 & $100.2 \pm 0.7$ & $65.3 \pm 0.2$ & $4.8 \pm 0.1$ & $1.6 \pm 0.1$ & $1.7 \pm 0.1$ & $73.4 \pm 0.5$ & 73.3 \\
\hline
\end{tabular}

Among the experimental groups, the three-breed piglets $(\mathrm{LW} \times \mathrm{ST}) \times \mathrm{D}$ had an advantage in the ham weight over 3 and 4 groups by $0.2-0.4 \mathrm{~kg}(\mathrm{P}<0.95)$.

The morphological composition of carcasses gives the most complete picture of the meat-bearing qualities of purebred and crossbred young animals (Table 4).

Data on the morphological composition of carcasses indicate that the piglets obtained from the crossing of crossbred female pigs (LW $\times \mathrm{ST}$ ) with male pigs of Pietrain, Landrace, Duroc breeds in the carcass meat yield exceeded LW and crossbred female pigs $L W \times S T$, respectively, by 2.6\% ( $P>0.999) ; 3.3 \%(P>0.999) ; 4.0 \%(P>0.999)$ and 3.9\% $(P>0.999)$; 4.5\% ( $P>0.999) ; 5.3 \%(P>0.999)$.

TABLE 3: Meat qualities of piglets of different genotypes

\begin{tabular}{|c|c|c|c|c|c|c|} 
Group & Combination & $\mathrm{n}$ & $\begin{array}{c}\text { Semi- } \\
\text { carcass } \\
\text { weight, } \mathrm{cm}\end{array}$ & $\begin{array}{c}\text { Fat depth, } \\
\mathrm{mm}\end{array}$ & $\begin{array}{c}\text { Loin eye } \\
\text { area, } \mathrm{cm}^{2}\end{array}$ & $\begin{array}{c}\text { Back third } \\
\text { semi- } \\
\text { carcass } \\
\text { weight, } \mathrm{kg}\end{array}$ \\
\hline I & LW & 5 & $95.3 \pm 0.4$ & $31.4 \pm 0.3$ & $38.5 \pm 0.2$ & $9.9 \pm 0.1$ \\
\hline II & LW $\times$ ST & 5 & $95.1 \pm 0.4$ & $31.8 \pm 0.4$ & $38.1 \pm 0.3$ & $10.1 \pm 0.1$ \\
\hline III & $($ LW $\times$ ST $) \times$ P & 5 & $97.9 \pm 0.5$ & $27.4 \pm 0.3$ & $42.2 \pm 0.2$ & $10.6 \pm 0.1$ \\
\hline IV & (LW $\times$ ST $) \times$ L & 5 & $98.1 \pm 0.4$ & $27.3 \pm 0.2$ & $42.7 \pm 0.2$ & $10.8 \pm 0.1$ \\
\hline V & (LW $\times$ ST $) \times D$ & 5 & $98.4 \pm 0.3$ & $27.1 \pm 0.3$ & $43.6 \pm 0.3$ & $11.0 \pm 0.1$ \\
\hline
\end{tabular}


TABLE 4: Morphological composition of carcasses

\begin{tabular}{|c|c|c|c|c|c|c|c|c|}
\hline \multirow[t]{3}{*}{ Group } & \multirow[t]{3}{*}{ Combination } & \multirow{3}{*}{$\begin{array}{c}\text { Semi- } \\
\text { carcass } \\
\text { weight, } \\
\text { kg }\end{array}$} & \multicolumn{6}{|c|}{ Semi-carcass content } \\
\hline & & & \multicolumn{2}{|c|}{ meat } & \multicolumn{2}{|c|}{ fat } & \multicolumn{2}{|c|}{ bones } \\
\hline & & & $\mathrm{kg}$ & $\%$ & $\mathrm{~kg}$ & $\%$ & $\mathrm{~kg}$ & $\%$ \\
\hline । & LW & 30.5 & $17.2 \pm 0.3$ & 56.4 & $9.8 \pm 0.2$ & 32.1 & $3.5 \pm 0.1$ & 11.5 \\
\hline ॥ & $\mathrm{LW} \times \mathrm{ST}$ & 30.2 & $17.4 \pm 0.2$ & 57.6 & $9.3 \pm 0.2$ & 30.8 & $3.5 \pm 0.1$ & 11.6 \\
\hline III & $(\mathrm{LW} \times \mathrm{ST}) \times \mathrm{P}$ & 32.2 & $19.4 \pm 0.3$ & 60.3 & $9.1 \pm 0.2$ & 28.3 & $3.7 \pm 0.1$ & 11.5 \\
\hline IV & $(\mathrm{LW} \times \mathrm{ST}) \times \mathrm{L}$ & 32.0 & $19.5 \pm 0.2$ & 60.9 & $8.9 \pm 0.1$ & 27.8 & $3.6 \pm 0.1$ & 11.3 \\
\hline V & $(\mathrm{LW} \times \mathrm{ST}) \times \mathrm{D}$ & 32.6 & $20.1 \pm 0.2$ & 61.7 & $8.8 \pm 0.1$ & 27.0 & $3.7 \pm 0.1$ & 11.4 \\
\hline
\end{tabular}

The amount of fat in a carcass of the animals of the $1^{\text {st }}$ and $2^{\text {nd }}$ groups made 30.8 and $32.1 \%$, which was higher compared to the animals of the three-breed crossing by 2.5 $(P<0.95)$; $3.0(P<0.95)$; 3.8\% $(P>0.99)$ and 3.9 $(P>0.999) ; 4.3(P>0.999) ; 5.1 \%(P>0.999)$.

\section{Discussion}

The studies revealed that the two-breed LW $\times$ ST piglets had the largest amount of kidney fat followed by LW and piglets of all three-breed crossbreeding options. However, the difference is not statistically significant.

One of the main tasks of the study was to analyze the meat qualities of pigs obtained during the crossing of female pigs LW and half-breed LW $\times$ ST with the male pigs of specialized meat breeds (Pietrain, Duroc, Landrace). The loin eye area is a key indicator of the carcass meat content assessment. The piglets received by crossing the crossbred female pigs $L W \times S T$ with the $P, L$ and $D$ male pigs had the highest indicator of the loin eye area - 32.2; 32,7; and $33.6 \mathrm{~cm}^{2}$, which was higher than the LW pigs by $3.7 \mathrm{~cm}^{2}$ ( $P>0.999) ; 4.2 \mathrm{~cm}^{2}$ ( $\left.P>0.999\right) ; 5.1 \mathrm{~cm}^{2}$ ( $\left.P>0.999\right)$. In terms of the loin eye area the animals of the $2^{\text {nd }}$ group (LW $\times \mathrm{ST}$ ) lagged behind their LW analogs by $0.4 \mathrm{~cm}^{2}$.

In terms of the weight of the semi-carcass back third, the piglets of 3, 4, 5 experimental groups had a reliable advantage over purebred LW herdmates - by 0.7 ( $P>0.999) ; 0.9$ $(P>0.999)$ and $1.1 \mathrm{~kg}(P>0.999)$, respectively. For this indicator the crossbred piglets of the $2^{\text {nd }}$ group exceeded the animals of the control group by $0.2 \mathrm{~kg}(\mathrm{P}<0.95)$. 


\section{Conclusion}

Thus, the results of studies on meat qualities prove that the three-breed crossing animals $(\mathrm{LW} \times \mathrm{ST}) \times \mathrm{D}$ had the highest values, and their carcass length, fat density, loin eye area and semi-body back third weight made $98.4 \mathrm{~cm}, 27.1 \mathrm{~mm}, 33.6 \mathrm{~cm}^{2}$, and $11.0 \mathrm{~kg}$, respectively.

In terms of the amount of fat in a carcass, the animals of the $1^{\text {st }}$ and $2^{\text {nd }}$ groups exceeded the animals of the three-breed crossing.

The differences in bone content were not significant and statistically unreliable.

The piglets of all variants of three-breed crossing had the longest carcasses, which exceeded the LW herdmates and two-breed LW $\times$ ST cross breeds.

The three-breed piglets $(\mathrm{LW} \times \mathrm{ST}) \times \mathrm{D}$ had the thinnest fat layer.

Data on the morphological composition of carcasses indicate that the piglets obtained from the crossing of crossbred female pigs (LW X ST) with male pigs of Pietrain, Landrace, Duroc breeds in the carcass meat yield exceeded LW and crossbred female pigs LW $x$ ST.

\section{Acknowledgement}

The authors would like to thank their colleague for their contribution and support to the research. They are also thankful to all the reviewers who gave their valuable inputs to the manuscript and helped in completing the paper.

\section{Conflict of Interest}

The authors have no conflict of interest to declare.

\section{References}

[1] Moroz, O. G., et al. (2019). Slaughter and Meat Qualities of Highly Productive Hybrids of Pigs. Presented at Innovations in Animal Husbandry - Today and Tomorrow. Collection of Scientific Articles on the Materials of the International Scientific and Practical Conference dedicated to the $70^{\text {th }}$ anniversary of the Research and Practical Center of the National Academy of Sciences of Belarus on Animal Husbandry. December 2019, Zhdanovo, Belarus, Publishing House: Republican 
Unitary Enterprise "Belarusian Science Publishing House" (Minsk) p. 103-107.

[2] Semenov, A. S. and Kavardakova, O. Y. (2017). Effects of Intergenerational Crossbreeding on the Productive Quality of Pigs. Perm Agrarian Bulletin, vol. 4, issue 20, pp. 134-139.

[3] Chernova, S. E. and Kazakov, V. S. (2016). Slaughter and Meat Qualities of Store Pigs in Purebred and Industrial Crossbreeding. Science and World., vol. 10, issue 38, pp. 56-58.

[4] Shatskikh, E. V. (2018). Slaughter and Meat Qualities of Crossbred Pigs. Perm Agrarian Bulletin., vol. 2, issue 22, pp. 153-157.

[5] Samsonova, O. E. (2016). Meat Productivity of Pigs of Large White and Short-Eared White Breeds Crossed with Duroc Meat Breed Male Pigs. Presented at World Science: Problems and Innovations. Collection of Articles of the III International Scientific and Practical Conference. Publishing house: "Science and Education", Penza, Russia, pp. 148-150.

[6] Leonidov, I. N., Kozlikin, A. V. and Lodyanov, V. V. (2016). Reproduction, Feeding and Meat Qualities of Store Pigs when using Male Pigs of Specialized Breeds and Types. Polythematic Network Electronic Scientific Journal of Kuban State Agrarian University, issue 122, Vol. I, Scientific Journal of KubSAU, No. 122 (08), Krasnodar, Russia, pp. 89-98.

[7] Perevoiko, Z. A. and Semenov, A. S. (2017). Quality of Pig Carcasses and Meat Depending on Genotype and Body Weight During Slaughter. Presented at Key Problems and Advanced Developments in Modern Science. Collection of Scientific Works on the Materials of the I International Scientific and Practical Conference. Perm, Russia, pp. 96-100.

[8] Tarichenko, A. I. and Grishchenko, A. I. (2015). Nutritional and Biological Value of Pork. Presented at Innovative Technologies of Food Production. Materials of the International Scientific and Practical Conference. Persianovsky village, Russia, February, 2015, Publishing house: Federal State Budgetary Educational Institution of Higher Professional Education "Don State Agrarian University" (Persianovsky village) p. 136-140

[9] Doylidov, V. A., Lyakhova, E. N. and Zagorsky, V. V. (2016). Meat Qualities of Pigs of Different Weight Conditions. In Agrarian Science to Agriculture. Altai State Agrarian University. Barnaul, Russia, pp. 107-109.

[10] Miroshnichenko, I. P. and Kosov, V. A. (2019). Efficiency of Landrace Male Pigs when used with Large White Female Pigs. Scientific bulletin of Lugansk National Agrarian 
University of Lugansk People's Republic, issue 7-1, Vol. I, the scientific journal issue 7-1, pp. 449-457.

[11] Chepkasova, S. Y. (2018). Meat and Fattening Productivity of Pigs. In Permian Period. Collection of Materials of the V International Scientific and Sports Festival of Cadets and Students. Publishing house: Perm Institute of the Federal Penitentiary Service, Perm, Russia, Vol. II, May 2018, pp. 574-576.

[12] Kazantseva, N. P., Vasilyeva, M. I. and Sergeeva, I. N. (2019). Indicators of Pig Productivity in Different Crossbreeding Schemes. Perm Agrarian Bulletin. No., vol. 4 , issue 28 , pp. 99-106.

[13] Nisova, V. S. (2017). Effect of Genotype and Body Weight of Pigs on Meat Quality. In Permian Period. Collection of Materials of the IV International Festival of Cadets, Students and Learners. Perm Institute of the Federal Penitentiary Service of Russia, Perm, Russia, May 2017, Publishing house: Perm Institute of the Federal Penitentiary Service, pp. 425-427

[14] Tarichenko, A. I., et al. (2019). Productive Qualities of Store Pigs when using Male Pigs of Specialized Breeds. In Innovations in Food Production: from Animal Breeding to Food Production Technology. Materials of the International Scientific and Practical Conferences. Publishing house: Federal State Budgetary Educational Institution of Higher Professional Education "Don State Agrarian University", February, 2019, village. Persianovsky, Russia, pp. 282-286

[15] Chernobrovkina, A. P. (2017). Meat, Fattening and Slaughter Qualities of Purebred and Crossbred Pigs. In Permian Period. Collection of Materials of the IV International Festival of Cadets, Students and Learners, Publishing house: Perm Institute of the Federal Penitentiary Service, Perm, Russia, May, 2017, pp. 434-437. 